Original Paper

http://indexmedicus.afro.who.int

\title{
Effect of aeration on selected water quality parameters in freshwater fish culture
}

\author{
Ayoola Olusegun AKINWOLE ${ }^{1 *}$, Akeem Babatunde DAUDA ${ }^{2}$ \\ and Temitayo Ayokunle OREDEIN ${ }^{1}$ \\ ${ }^{I}$ Department of Aquaculture and Fisheries Management, University of Ibadan, \\ UI Post office, Ibadan, Oyo State, Nigeria. \\ ${ }^{2}$ Department of Fisheries and Aquacultural Technology, Federal University Dutsin-Ma, \\ PMB 5001, Dutsin-Ma, Katsina State, Nigeria. \\ *Corresponding author; E-mail: akinwoolu@yahoo.com,tdabak@gmail.com; Tel: +2348033600554
}

\begin{abstract}
This paper report findings of an investigation into the effect of aeration devices on some selected freshwater quality parameters. Three aeration columns, Upturned shower rose (USR), Downturned shower rose (DSR) and Perforated pipe (PEP) were experimented. Freshwater fish culture water was passed through the devices and analysed for Temperature, $\mathrm{pH}$, Alkalinity and Dissolved oxygen (DO) in the morning, afternoon and evening. The percentage modification was used to measure the effect of aeration on the selected water quality parameters. Temperature modification ranged from $-2.4 \%$ to $0 \%$ with equal value in all the aeration devices at all the period, Alkalinity ranged between $-10.7 \%$ and $3.7 \%$ with least modification in DSR in the morning but highest in USR in the evening, The percentage modification in $\mathrm{pH}$ fell between $-8.3 \%$ and $-1.8 \%$ with the least modification in USR in the morning while the highest was recorded also in USR but in the evening. The DO ranged between $37.1 \%$ to $161.9 \%$ with the highest modification in DSR in the afternoon and the lowest in USR in the evening. The investigated aerating devices have little effect on all the selected water quality parameters, except for dissolved oxygen where the effect is very prominent.
\end{abstract}

(C) 2014 International Formulae Group. All rights reserved.

Keywords: Aeration columns, aquaculture, downturned shower rose, freshwater quality, perforated pipe, upturned shower rose,

\section{INTRODUCTION}

Water is one of the most important and abundant compound of the ecosystem. It has social and economic benefit to man especially when it is properly utilised (Jenyo-Oni et al., 2010). It has been used over the years for various purposes such as domestic water supply, irrigation, hydroelectric power generation, recreation and fish production (Mustapha, 2006). Due to increased human population, industrialisation, use of fertilizers in the agriculture and man-made activities, water is polluted with different harmful contaminants which leads to the pollution of 
aquatic ecosystems and gradually leads to degradation of the water quality for the survival of aquatic organisms (AbdelShafy and Aly, 2002). Water quality affects the general condition of cultured organism as it determines its health and growth (Akinwole and Adeola, 2012). There are many water quality parameters in an aquatic environment but only a few of them play significant roles in fish culture (Jenyo-Oni et al., 2010). Among this few are dissolved oxygen, temperature, $\mathrm{pH}$, alkalinity and Nitrogenous wastes compounds (Ammonia, Nitrate and Nitrite). Dissolved oxygen is the most critical water quality variable in aquaculture (Boyd, 1998) and it is essential to all forms of aquatic life. The problem of oxygen depletion in rearing of freshwater fish species is a major threat in aquaculture because it leads to hypoxia which affects fish growth and food conversion levels, etc (Mallya, 2007). Enhancement of dissolved oxygen in water can be facilitated by an efficient and cost effective aeration column through the process of aeration. Apart from increasing the dissolved oxygen level of water, aeration column can also be used for degasification and oxygenation (increase in oxygen gas by aeration leads to decrease in harmful gases like carbon dioxide, hydrogen sulphide, etc.). There are several ways of oxygenating water and it includes the use of fountains, sprinklers, electrical operated aerators, etc. (Brown, 2003). The use of simple aeration columns which are cost effective would readily solve the problem of low dissolved oxygen in freshwater culture systems. This will help maintain water at optimal levels and hereby reduce the cost of production, thereby increasing the profit margin of aquaculturists. However, it is important to have information on the impact of aeration on other important water quality parameters in fish culture which includes temperature, $\mathrm{pH}$, alkalinity. Temperature is an important water quality parameter and in an established aquaculture system the water temperature controls the rate of all chemical reactions, and affects fish growth, reproduction and immunity (Gupta et al., 2009). Alkalinity is the measure of the capacity of water to neutralize or buffer acids using carbonate, bicarbonate ions, and in rare cases, by hydroxide, thus protecting the organisms from major fluctuations in $\mathrm{pH}$ (Kelly et al., 2004). pH is defined as the negative logarithm of the hydrogen ion concentration, fish can become stressed or die when exposed to $\mathrm{pH}$ extremes or when $\mathrm{pH}$ changes rapidly, even if the change occurs within a $\mathrm{pH}$ range that is normally tolerated (Tucker and D'Abramo, 2008). At approximately $\mathrm{pH} 4.0$ or below and $\mathrm{pH} 11$ or above, most species die, for most freshwater species, a pH range of $6.5-9.0$ is ideal (Ajani et al., 2011). This paper report, findings of a study which investigated the effect of three aeration devices on some selected water quality parameters in freshwater fish culture system.

\section{MATERIALS AND METHODS}

The study was carried out in the Department of Aquaculture and Fisheries Management laboratory, University of Ibadan. Deep well water majorly used for fish culture experiment and other activities in the laboratory was used as the water source. The well has a depth of $600 \mathrm{~cm}$ with the water level of $400 \mathrm{~cm}$ from the ground

\section{Aeration columns}

Three different aeration columns were used for the experiment, namely; Upturned shower rose (USR), Downturned shower rose (DSR) and Perforated pipe (PEP). Each of them was attached to transparent plastic water tank of 36.5 by $26.5 \mathrm{~cm}$. Aeration column one, (Upturned shower rose (USR)) was positioned at the base of the plastic tank, an upturned shower rose was attached to a pipe 5 $\mathrm{cm}$ from the base of the tank with a butterfly valve for the control of water flow from the tank through the aeration device to the receiving tank. Aeration column two, (Downturned shower rose (DSR)) was fitted at the base of the plastic tank. It is a 
downturned shower rose attached to a pipe of $5 \mathrm{~cm}$ long, fitted with a butterfly valve for the control of water flow from the tank through the aeration device to the receiving tank, with an elbow joint and a $2 \mathrm{~cm}$ extension from which the shower rose was attached facing down. Aeration column three, (Perforated pipe (PEP)) was positioned at the base of the plastic tank. It is a $5 \mathrm{~cm}$ long plastic pipe, fitted with a butterfly valve, with a t-joint and $2 \mathrm{~cm}$ pipes attached at each side of the t-joint, there are four holes running horizontally under the pipe with a diameter of $25 \mathrm{~cm}$ each. These water tanks were placed so that the aeration columns were at the distance of 119 $\mathrm{cm}$ from the receiving tank below, the DSR was placed on a stand of $4.5 \mathrm{~cm}$ and the PEP was placed on a wooden stand of $2 \mathrm{~cm}$ while USR maintained the $119 \mathrm{~cm}$ initial height, this was done so that the aeration columns can discharge water from the same level and maintain equal potential head during the experimental process (Figure 1).

\section{Experimental procedure}

The experiment was carried out three times daily between February and March 2014, it was done between 0730-0800 hours, 1330-1400 hours and 1930-2000 hours. The water sample was collected from the well and taken to the laboratory immediately for the analysis. The water was analysed for the selected water quality parameters before and after running through the system, outflow water measurements were taken after four minutes of flowing, the water samples were collected at $2 \mathrm{~cm}$ below the water surface. All the experiment was carried out in triplicates.

\section{Water quality analysis}

The inflow and outflow were analysed for dissolved oxygen (DO), $\mathrm{pH}$, Temperature and Alkalinity. The DO was measured using NTLABS dissolved oxygen test kit, Temperature was determined using mercuryin-glass thermometer graduated in the degree Celsius $\left({ }^{0} \mathrm{C}\right)$, in line with Atobatele et al. (2005). Alkalinity was determined using
$\mathrm{HACH}$ test kit while the $\mathrm{pH}$ was determined using LABTECH Photic 20 digital $\mathrm{pH}$ meter probe.

\section{Data/statistical analysis}

The percentage modification was estimated as

$$
\% \text { modification }=\frac{(\mathrm{MFV}-\mathrm{MIV}) \times 100}{\text { Mean initial value }}
$$

MFV: Mean final value

MIV: mean initial value

Simple descriptive statistics, ANOVA and regression analysis was used to analyse the data obtained. All analysis was done using IBM SPSS version 20 .

\section{RESULTS}

\section{Modification of water quality parameters}

The mean values of selected water quality parameters are shown in Table 1 .Temperature ranged between $28.3 \pm 0.57{ }^{\circ} \mathrm{C}$ and $29.3 \pm 1.15{ }^{\circ} \mathrm{C}$ and the percentage modification in temperature ranged from $2.4 \%$ to $0 \%$, the highest modification though negative was recorded in all the columns in the afternoon with no difference among the columns. Alkalinity had its mean values ranged from $251.1 \pm 6.17 \mathrm{mg} / \mathrm{l}$ to $258.5 \pm 6.48$ $\mathrm{mg} / \mathrm{l}$, with highest value in USR in the evening and least value in DSR in the morning. Its percentage modification ranged between $-10.7 \%$ and $3.7 \%$, the highest was recorded in USR in the evening while the lowest was obtained in DSR in the morning. While positive modification was recorded for all the columns in the afternoon and evening, negative modification was recorded in the entire column in the morning. The $\mathrm{pH}$ values ranged between $6.53 \pm 0.28$ to $6.65 \pm 0.13$, the highest $\mathrm{pH}$ was recorded in USR in the evening while the least was recorded in DSR in the afternoon. The percentage modification in $\mathrm{pH}$ fell between $-8.3 \%$ and $-1.8 \%$ with the highest recorded in USR in the evening while the least was recorded also in USR but in the morning. The DO had its mean value between $4.7 \pm 0.76 \mathrm{mg} / \mathrm{l}$ and $5.6 \pm 0.28 \mathrm{mg} / \mathrm{l}$, with the 
highest value in DSR and the lowest in USR both in the morning. While the percentage modification ranged between $37.1 \%$ to $161.9 \%$ with the highest modification in DSR in the afternoon and the lowest in USR in the evening. ANOVA did not show any significant difference $(\mathrm{P}>0.05)$ among the three aerators for all the water quality parameters.

\section{Interdependence and interrelationships among water quality parameters}

The correlation coefficient showed the level of interdependence among the water quality parameters, there was significant relationship only between temperature and DO with correlation co-efficient of -0.220 and
$\mathrm{pH}$ and alkalinity with correlation co-efficient of 0.958 (Table 2).

The simple linear and multi-linear regression analysis (Tables 3 and 4) showed the interrelationship among the water quality parameters. In simple linear regression DO showed significant relationship with only temperature $\left(\mathrm{R}^{2}=0.432\right)$ with prediction equation, $\mathrm{D} . \mathrm{O}=-0.036 \mathrm{~T}+6.19$, while $\mathrm{pH}$ also showed significant relationship with only Alkalinity. $\left(\mathrm{R}^{2}=0.637\right)$, with prediction equation, $\mathrm{pH}=0.015 \mathrm{AL}+2.57$. For multilinear regression Alkalinity showed significant relationship with $\mathrm{pH}$ and Temperature $\left(\mathrm{R}^{2}=0.637\right)$, with prediction equation $\mathrm{AL}=37.24 \mathrm{pH}+1.800 \mathrm{~T}-44.83$.

Table 1: Interdependence of the water quality parameters during the period of the study.

\begin{tabular}{|c|c|c|c|c|}
\hline & $\begin{array}{c}\text { Temperature } \\
\left({ }^{0} \mathrm{C}\right)\end{array}$ & DO (mg/l) & pH & Alkalinity(mg/l) \\
\hline Temperature $\left({ }^{0} \mathrm{C}\right)$ & 1 & -0.220 & 0.160 & 0.283 \\
\hline $\mathrm{DO}(\mathrm{mg} / \mathrm{l})$ & $-0.220 * *$ & 1 & -0.607 & -0.545 \\
\hline $\mathrm{pH}$ & 0.160 & -0.607 & 1 & $0.958 *$ \\
\hline Alkalinity(mg/l) & 0.283 & -0.545 & 0.958 & 1 \\
\hline
\end{tabular}

Table 2: Linear regression analysis among selected water quality parameters during the period of study.

\begin{tabular}{lccc}
\hline Y & X & Prediction equation & $\begin{array}{c}\text { Determination } \\
\text { Coefficients }\left(\mathbf{R}^{2}\right)\end{array}$ \\
\hline Dissolved oxygen & Temperature & $\mathrm{D} . \mathrm{O}=-0.036 \mathrm{~T}+6.19$ & $0.432^{*}$ \\
Alkalinity & Temperature & $\mathrm{AL}=3.266 \mathrm{~T}+157.36$ & 0.349 \\
$\mathrm{pH}$ & Temperature & $\mathrm{pH}=0.039 \mathrm{~T}+5.42$ & 0.120 \\
Dissolved oxygen & Alkalinity & $\mathrm{DO}=0.042 \mathrm{AL}+15.93$ & 0.167 \\
Temperature & Alkalinity & $\mathrm{TEMP}=-0.053 \mathrm{AL}+15.22$ & 0.174 \\
$\mathrm{pH}$ & Alkalinity & $\mathrm{pH}=0.015 \mathrm{AL}+2.57$ & $0.637 *$ \\
\hline *shows significance & & &
\end{tabular}


A. O. AKINWOLE et al. / Int. J. Biol. Chem. Sci. 8(6): 2858-2865, 2014

Table 3: Mean values and percentage modification of water quality parameters recorded during the study.

\begin{tabular}{|c|c|c|c|c|c|c|c|}
\hline \multirow[t]{2}{*}{ Parameters and units } & \multirow[b]{2}{*}{ Initial } & \multicolumn{2}{|c|}{ USR } & \multicolumn{2}{|r|}{ DSR } & \multicolumn{2}{|r|}{ PEP } \\
\hline & & Final & $\%$ modification & Final & $\%$ modification & Final & $\%$ modification \\
\hline \multicolumn{8}{|l|}{ Morning } \\
\hline Temperature $\left({ }^{0} \mathrm{C}\right)$ & $29.3 \pm 1.15$ & $29.3 \pm 0.57$ & 0 & $29.3 \pm 0.57$ & 0 & $29.3 \pm 0.57$ & 0 \\
\hline $\mathrm{pH}$ & $7.13 \pm 0.40$ & $6.54 \pm 0.15$ & -8.3 & $6.61 \pm 0.15$ & -7.2 & $6.64 \pm 1.02$ & -6.8 \\
\hline Alkalinity (mg/l) & $281.5 \pm 2.50$ & $252.2 \pm 3.16$ & -10.4 & $251.1 \pm 6.17$ & -10.7 & $256 \pm 13.67$ & -9.05 \\
\hline Dissolved oxygen(mg/l) & $2.8 \pm 0.57$ & $4.7 \pm 0.76$ & 67.8 & $5.6 \pm 0.28$ & 100 & $5.1 \pm 0.76$ & 82.1 \\
\hline \multicolumn{8}{|l|}{ Afternoon } \\
\hline Temperature $\left({ }^{0} \mathrm{C}\right)$ & $30.6 \pm 0.57$ & $29.6 \pm 0.57$ & -3.2 & $29.6 \pm 0.57$ & -3.2 & $29.6 \pm 0.57$ & -3.2 \\
\hline $\mathrm{pH}$ & $6.84 \pm 0.32$ & $6.65 \pm 0.08$ & -2.7 & $6.53 \pm 0.28$ & -2.7 & $6.63 \pm 0.24$ & -3.0 \\
\hline Alkalinity $(\mathrm{mg} / \mathrm{l})$ & $250.5 \pm 40.80$ & $256.7 \pm 3.5$ & 2.4 & $251.1 \pm 11.1$ & 0.2 & $256 \pm 3.92$ & 2.1 \\
\hline Dissolved oxygen(mg/l) & $2.1 \pm 0.28$ & $4.8 \pm 0.28$ & 128.5 & $5.5 \pm 0.5$ & 161.9 & $5.2 \pm 0.5$ & 147.6 \\
\hline \multicolumn{8}{|l|}{ Evening } \\
\hline Temperature $\left({ }^{0} \mathrm{C}\right)$ & $29 \pm 1.15$ & $28.3 \pm 0.57$ & -2.4 & $28.3 \pm 0.57$ & -2.4 & $28.3 \pm 0.57$ & -2.4 \\
\hline $\mathrm{pH}$ & $6.73 \pm 0.24$ & $6.65 \pm 0.13$ & -1.8 & $6.56 \pm 0.20$ & -2.5 & $6.57 \pm 0.07$ & -2.3 \\
\hline Alkalinity $(\mathrm{mg} / \mathrm{l})$ & $249.1 \pm 22.6$ & $258.5 \pm 6.48$ & 3.7 & $252.9 \pm 8.38$ & 1.5 & $53.4 \pm 3.08$ & 1.7 \\
\hline Dissolved oxygen(mg/l) & $3.5 \pm 0$ & $4.8 \pm 0.28$ & 37.1 & $5.5 \pm 0.5$ & 57.1 & $5.1 \pm 0.28$ & 45.7 \\
\hline
\end{tabular}


Table 4: Multi-linear regression analysis of selected water quality parameters during the study period.

\begin{tabular}{lccc}
\hline Y & $\mathbf{X}$ & Prediction equation & $\begin{array}{c}\text { Determination } \\
\text { Coefficients }\left(\mathbf{R}^{2}\right)\end{array}$ \\
\hline Dissolved oxygen & $\mathrm{pH}$ & $\begin{array}{c}\text { D.O. }=-1.523 \mathrm{pH}+ \\
0.023 \mathrm{~T}+14.46\end{array}$ & 0.079 \\
& Temperature & $\mathrm{pH}$ & $\mathrm{AL}=37.24 \mathrm{pH}+$ \\
Alkalinity & & $1.800 \mathrm{~T}-44.83$ & $0.686^{*}$ \\
& & & \\
& Temperature &
\end{tabular}

Upturned shower rose

Support base

Water tank

Downturned shower rose

Perforated pipe

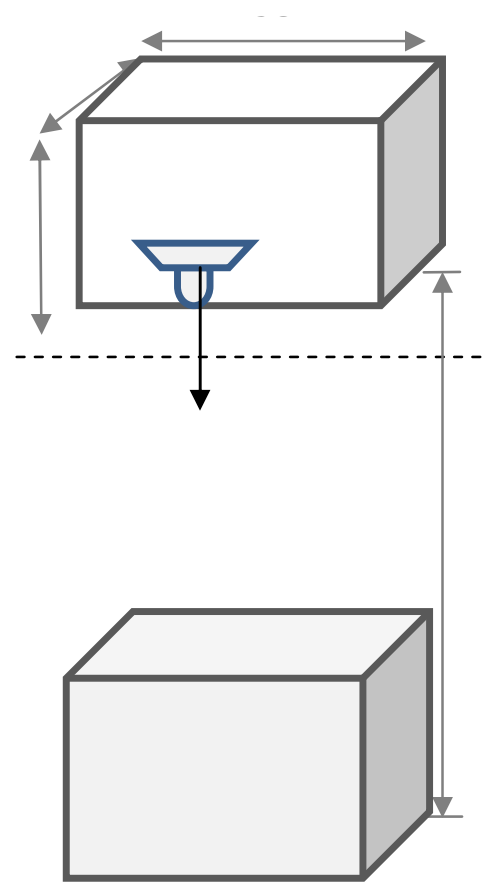

USR

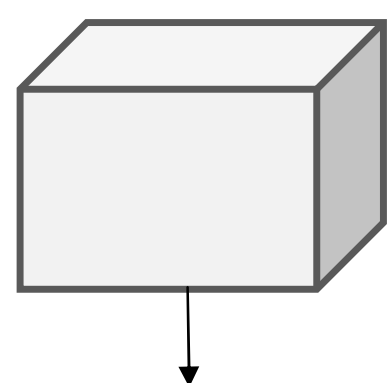

DSR

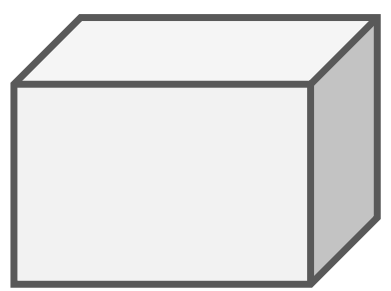

PEP

Collection tank

*All dimensions are in centimetres $(\mathrm{cm})$

Figure 1: Sketch of the three aeration columns investigated. 


\section{DISCUSSION}

Modification of water quality parameters

The highest values of temperature recorded in the afternoon can be attributed to the prevailing weather condition being dry season with characteristics sunny afternoon. Temperature and $\mathrm{pH}$ experience negative modification, alkalinity experience positive modification except in the morning while DO experienced positive modification at all the period. The DO value increases while the temperature and $\mathrm{pH}$ reduces, this may be due to the effect of degasification by aeration (USEPA, 1998). The percentage modification in all the water quality parameters except DO was small, this showed that aeration of water, though significantly increase the DO in culture water, it has a little influence on other water quality parameters, and this is in line with observation of Das et al. (2004). The effect is not harmful to fish to be cultured because all the water quality parameters still fell in line with recommendation for fish culture (Akinwole and Adeola, 2012). However, on general comparison the, DSR did relatively better at all the period.

\section{Interdependence and interrelationships} among water quality parameters

DO and temperature exhibited negative correlation; this is similar to observation of Dauda and Akinwole (2014). This established an inverse relationship between the two parameters, indicating that more oxygen tend to dissolve at high temperature and vice versa. Alkalinity and $\mathrm{pH}$ exhibit strong positive correlation, this indicated that increase in $\mathrm{pH}$ may lead to increase in alkalinity and vice versa.

This significant interrelationship that existed between DO and temperature indicated that with knowledge of temperature, DO can be estimated, a similar observation was reported by Dauda and Akinwole (2014) while For alkalinity, knowledge of $\mathrm{pH}$ or $\mathrm{pH}$ and Temperature will give the estimate, this relationship and equations can give an idea especially during urgent need but not necessarily replacing scientific procedures.

\section{Conclusion}

The results of this study indicated that all the investigated aerating columns have good tendency for dissolved oxygen enhancement in freshwater fish culture and with little effect on other water quality parameters at a level that is not harmful to the cultured organism. The modification to water quality parameters is similar among the three aeration columns, the downturned shower rose however performed relatively better.

\section{REFERENCES}

Abdel-Shafy HI, Aly RO. 2002. Water Issue in Egypt: Resources, Pollution and Protection Endeavors. CEJOEM, 8(1): 321.

Ajani EK, Akinwole AO, Ayodele IA. 2011. Fundamentals of Fish Farming in Nigeria. Walecrown Publishers Ibadan: Ibadan; 158p.

Akinwole AO, Adeola IO. 2012. Interrelationship of Temperature, $\mathrm{pH}$, Dissolved Oxygen and Nitrogenous waste in Fish culture systems. NJRED, 6: 38-42.

Atobatele OE, Morenikeji OA, Ugwumba OA. 2005. Spatial Variation in physical and Chemical Parameters and Benthic macro-invertebrate Fauna of River Ogunpa, Ibadan. The Zoologist, 3: 58-67.

Boyd CE. 1998. Pond Aquaculture Water Quality Management. Kluwer Academic Publishers: Boston, MA; 700.

Brown TR. 2003. Evaluation of Aeration Technology for the Stockton Deep Water Ship Channel, CALFED Project No. 01N61-05. CALFED Bay-Delta Program Sacramento CA., 103 p.

Das PC, Ayyappan S, Jena JK, Singh SK, Patamajhi P, Muduli HK. 2004. Effect of Aeration on Production and Water Quality Changes in Intensive Carp Culture. Indian J. Fish. 51(2): 173-183.

Dauda AB, Akinwole AO. 2014. Interrelationships among Water Quality 
Parameters in Recirculating Aquaculture System. NJRED., 8: 20-25.

Gupta DP, Sunita J, Saharan P. 2009. Physiochemical Analysis of Ground Water of Selected Area of Kaithal City (Haryana) India. Researcher, 1(2): 1-5.

Jenyo-Oni A, Akinwole AO, Dauda AB. 2010. Benthic Macro-invertebrates and Physico Chemical Quality of Reservoirs in University of Ibadan, Fish Farm. IJAR, 6: 19-26.

Kelly A, Green L, Herron E. 2004. pH and alkalinity, URI Watershed Watch, Cooperative Extension. URIWW, 3: $1-4$.

Mallya YJ. 2007. The effects of dissolved oxygen on fish growth in aquaculture,
United Nations University, Fisheries Training Programme, UNU-FTP, $30 \mathrm{pp}$.

Mustapha MK. 2006. Effect of Human activities on Biodiversity of a tropical Man-made lake, Nigeria. Pure and Applied Science, 21:1960-1968.

Tucker CS, D’Abramo LR. 2008. Managing High $\mathrm{pH}$ in Freshwater Ponds. Southern Regional Aquaculture Centre, SRAC Publication No. 4604; 5p.

USEPA. 1998. Design Manual - Fine Pore Aeration Systems. EPA/630/R-95/001F, Apr 1998. http://www.epa.gov/raf/ publications/design-manual-fine-poreaeration-systems.htm (Accessed 15th July 2013). 